TECHNICAL NOTES AND MANUALS

Administering the Value-Added Tax on Imported Digital Services and Low-Value Imported Goods

John Brondolo and Mark Konza

Fiscal Affairs Department

I NTERNATIONAL MONETARY FUND 
INTERNATIONAL MONETARY FUND

Fiscal Affairs Department

\section{Administering the Value-Added Tax on Imported Digital Services and Low-Value Imported Goods}

Prepared by John Brondolo and Mark Konza ${ }^{1}$

Authorized for distribution by Michael Keen²

March 2021

DISCLAIMER: This Technical Guidance Note should not be reported as representing the views of the IMF. The views expressed in this paper are those of the authors and do not necessarily represent the views of the IMF, its Executive Board, or IMF management.

\begin{tabular}{|ll|}
\hline JEL Classification Numbers: & H250 \\
\hline Keywords: & $\begin{array}{l}\text { Tax administration, Value-Added Tax, Goods and Services Tax, } \\
\text { E-Commerce, Cross-Border Digital Services; Low-Value } \\
\end{array}$ \\
Imported Goods \\
\hline Authors' E-Mail Addresses: & $\begin{array}{l}\text { jbrondolo@IMF.org } \\
\text { mark.konza@gmail.com }\end{array}$ \\
\hline
\end{tabular}

John Brondolo is a Senior Economist in the IMF's Fiscal Affairs Department (FAD). Mark Konza is a member of FAD's roster of fiscal experts.

2 This note has benefited from information, guidance and comments provided by: Adrian PrestonLoh, Gary Artuso, Jenny Chen, and Tim Renner (Australian Taxation Office); Sze Teen Wong (Inland Revenue Authority of Singapore); Laurent Amalric (Direction Générale des Finances Publiques, France); David Jordan and Shanae Sherriff (Inland Revenue Department of New Zealand); Joydhan Barua, Arnulf Rabben, and Guri Ellen Stange (Norway Tax Administration); Andja Komso, Michael Keen, Cindy Negus, Azael Perez, Enrique Rojas, Christophe Waerzeggers, and Shitian Wang (International Monetary Fund); and Richard Asquith and Jerry Wellens. 


\section{TECHNICAL NOTES AND MANUALS}

\section{Administering the Value-Added Tax on}

Imported Digital Services and Low-Value Imported Goods

Prepared by John Brondolo and Mark Konza

\section{This technical note addresses the following questions:}

- What are the main challenges in administering the value-added tax on imported digital services and the measures that countries have introduced to address the challenges?

- What are the main challenges in administering the value-added tax on low-value imported goods and the measures that countries have introduced to address the challenges?

- What are the key tasks in implementing the measures for improving the administration of the value-added tax on imported digital services and low-value imported goods? 
Cross-border sales of goods and services have become a growing challenge to tax administration. Two particular challenges involve administering the value-added tax (VAT) on: (1) imported digital services and (2) low-value imported goods. In both cases, the rapid increase in cross-border transactions, brought about by digitalization and the rise of digital platform companies, combined with weaknesses in collecting VAT on those transactions have raised concerns that growing amounts of tax revenue may be foregone and domestic businesses may be at a competitive disadvantage vis-à-vis non-resident businesses. Concerns have also been raised that the current practices create risks of offshoring by domestic businesses to avail themselves of the more favorable VAT treatment

In response to those challenges, an increasing number of countries are adopting new approaches to administering the VAT on imported digital services and low-value imported goods. This note describes the vendor collection model under which non-resident suppliers are required to register for VAT in those foreign jurisdictions where they make supplies to final consumers, ${ }^{3}$ charge and collect VAT on those supplies, and remit the revenue to the foreign jurisdiction. This approach has been implemented by more than 60 countries for imported digital services and, more recently, by a growing number of countries for low-value imported goods. The note also describes the application of the reverse charge mechanism to collecting VAT on digital (and nondigital) services imported by businesses.

As an alternative to the vendor collection method, a few countries, particularly in Latin America, require financial intermediaries (e.g., banks and payment service providers) to withhold VAT on consumers' payments to foreign businesses. Although outside the scope of this note, it should be pointed out that the financial intermediary withholding model has several weaknesses, including that it is generally restricted to a list of selected businesses (thereby raising neutrality concerns) and can be difficult to operate since the financial institutions do not routinely collect the transactions data required to determine their VAT treatment (thereby raising efficiency and effectiveness concerns).

The note draws mainly on the practices of four countries: Australia, New Zealand, Norway, and Singapore. ${ }^{4}$ These countries' practices are representative of the vendor collection approach that is workable in other IMF member countries, including those with less advanced tax administrations. Section I addresses issues concerning imported services, Section II covers low-value imported goods, and Section III describes key tasks for implementing both the imported services and low-value imports regimes. European Union practices are highlighted in Appendix I.

3 The note deals specifically with the administration of the VAT. It does not address issues concerning the administration of digital services taxes.

4 Australia, New Zealand, Norway, and Singapore for imported digital services. Australia, New Zealand, and Norway for low-value imported goods. 


\section{CONTENTS}

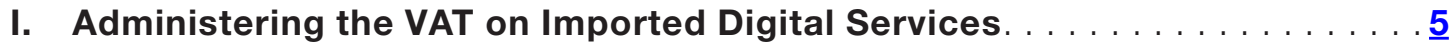

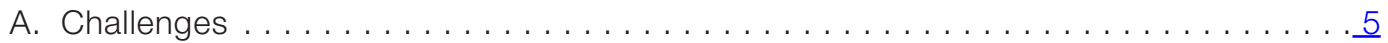

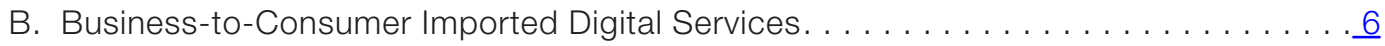

C. Business-to-Business Imported Digital Services. . . . . . . . . . . . . . . 13

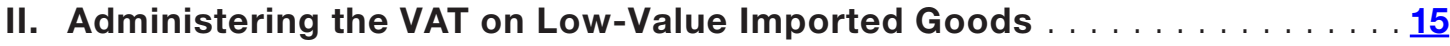

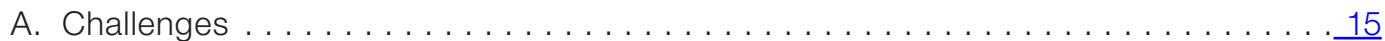

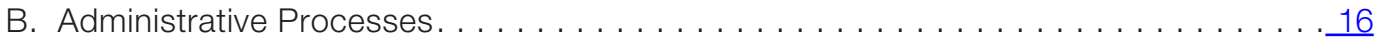

C. Coordination with Customs . . . . . . . . . . . . . . . . . . . . . . . 19

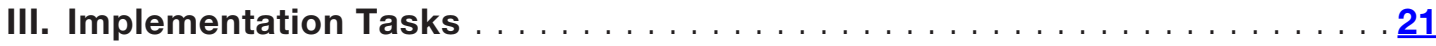

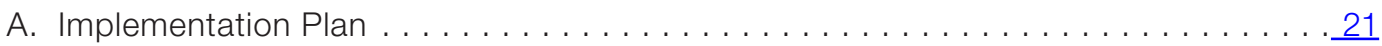

B. Legislative Changes. . . . . . . . . . . . . . . . . . . . 21

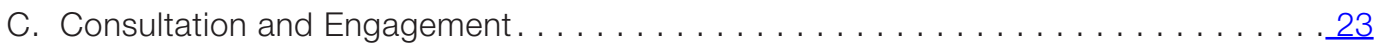

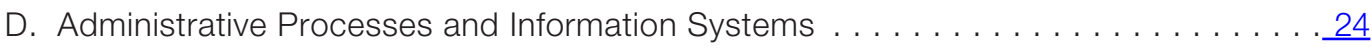

E. Taxpayer Education Outreach and Tax Officer Training . . . . . . . . . . . . . 28

\section{Boxes}

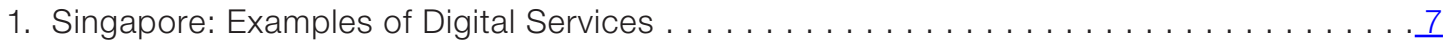

2. Applying Proxy Indicators to Determine a Consumer's Status $\ldots \ldots \ldots \ldots \ldots \ldots \ldots$

3. Third-Party Data Sources ............................... 11

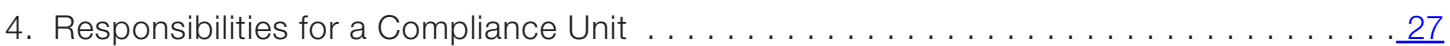

\section{Figures}

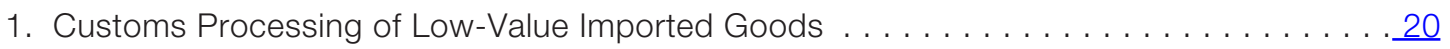

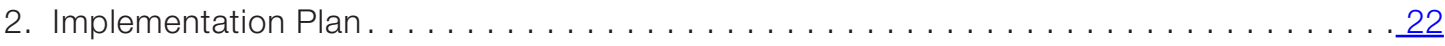

3. Sample Simplified Registration Form. . . . . . . . . . . . . . . . . . . 25

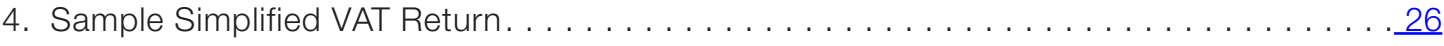

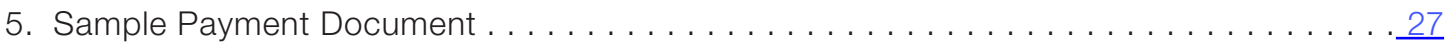

\section{Tables}

1. Imported Digitally-Delivered Services in Selected Countries. . . . . . . . . . . . . . . 6

2. Key Legislative Changes for the Imported Digital Services and

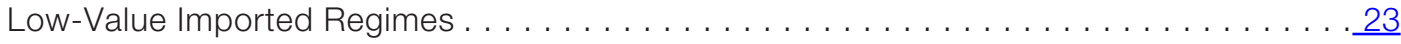

\section{Appendixes}

1. European Union Digital Services and Low-Value Imported Goods Schemes . . . . . . . . . . 29

2. Example of Determining the Scope of the Vendor Collection Regime (Singapore) . . . . . . 33

3. Example of Deeming an Electronic Marketplace as the Supplier for Businesses that Make Taxable Supplies on the Platform (Singapore) . . . . . . . . . . . . . . 34

4. Example of a Simplified Registration Form (New Zealand) . . . . . . . . . . . 35 


\title{
ACRONYMS
}

\author{
ABN . . . . . . Australian Business Number \\ B2B . . . . . . . Business-to-Business \\ B2C . . . . . . Business-to-Consumer \\ EU . . . . . . European Union \\ EUR . . . . . Euro \\ GST . . . . . . Goods and Services Tax \\ IMF ....... International Monetary Fund \\ IOSS ...... Imports One-Stop Shop \\ LVIG. . . . . . Low-Value Imported Goods \\ Moss .... . Mini One-Stop Shop \\ OECD. . . . . . Organization of Economic Cooperation and Development \\ OSS ....... One-Stop Shop \\ SWIFT . . . . Society for Worldwide Interbank Financial Telecommunications \\ TV ....... Television \\ UNCTAD ... United Nations Conference on Trade and Development \\ UK . . . . . . United Kingdom \\ US . . . . . . United States \\ VAT ....... Value-Added Tax
}




\section{ADMINISTERING THE VAT ON IMPORTED DIGITAL SERVICES}

\section{A. Challenges}

The destination principle is the international norm for applying the value-added tax to crossborder transactions. This principle is designed to achieve neutrality in international trade by ensuring that the VAT on cross-border supplies is ultimately levied only in the jurisdiction where the final consumption occurs. This is achieved by taxing imports on the same basis as domestic supplies and allowing exports to be supplied VAT-free (i.e., taxed at a 0 rate with a refund for any VAT paid on inputs used to produce the exports). ${ }^{5}$

While the destination principle has been widely accepted as the basis for applying VAT to international transactions, its application to cross-border services is complicated by the intangible nature of those services, which prevents the tax from being collected through physical customs control at the border. In addition, non-resident suppliers of services often have no physical presence in the importing country that could be made liable for collecting the VAT. ${ }^{6}$ At the same time, efforts at requiring final consumers to self-assess and pay VAT on their purchases of imported services have proven unworkable in most jurisdictions.

For many years, these challenges were not a major concern because few services could be performed across borders. With little revenue at risk, many countries either did not include imported services in their VAT base or did not find it necessary to establish effective methods for collecting VAT on these supplies.

The recent surge in imported digital services ${ }^{7}$ has led tax agencies to give greater attention to administering the VAT on imported services in general and digital services in particular. As shown in Table 1, imported digital services in 22 countries have increased by a weighted average of nearly 60 percent since 2010. ${ }^{8}$ As a consequence, countries have become increasingly concerned that no or inappropriately low amount of VAT is collected from these supplies and that domestic businesses (who must charge VAT) are placed at a competitive disadvantage relative to non-resident businesses (who do not charge VAT).

In recent years, countries have taken actions to improve the collection of VAT on imported digital services. These actions have been guided by the OECD report International VAT

Guidelines $^{9}$ which sets out recommendations for collecting VAT on cross-border supplies of services (including digital services) and intangibles. ${ }^{10}$ Separate guidelines have been established for businessto-consumer (B2C) and business-to-business (B2B) transactions.

5 Refer to the OECD International VAT/GST Guidelines on Neutrality, June 2011.

6 For ease of presentation, value-added tax is used synonymously with goods and services tax (GST).

7 Also commonly referred to as digital products or electronic services.

8 It should be noted that a large proportion of imported digital services reported in Table 1 may not generate VAT revenue either because the services represent business-to-business transactions, are supplied by non-resident businesses with sales below the VAT registration threshold, or are exempt or zero-rated.

9 Refer to the OECD's International VAT Guidelines (2017) at https://www.oecd.org/ctp/international-vat-gstguidelines-9789264271401-en.htm.

10 Further guidance is provided in the OECD report Mechanisms for effective collection of VAT on online sales (2017) at https://www.oecd.org/tax/consumption/mechanisms-for-the-effective-collection-of-vat-gst.htm 
TABLE 1. Imported Digitally-Delivered Services in Selected Countries (US\$ millions)

\begin{tabular}{|c|c|c|c|c|}
\hline & 2010 & 2015 & 2019 & $\begin{array}{l}\text { PERCENT } \\
\text { CHANGE }\end{array}$ \\
\hline Argentina & $5,453.6$ & $6,984.0$ & $7,010.1$ & 28.5 \\
\hline Cameroon & 902.7 & 569.4 & 946.3 & 4.8 \\
\hline Canada & $44,994.8$ & $47,882.1$ & $53,906.3$ & 19.8 \\
\hline France & $90,135.2$ & $129,139.5$ & $137,232.2$ & 52.3 \\
\hline Germany & $112,280.2$ & $143,198.2$ & $177,484.8$ & 58,1 \\
\hline India & $43,520.6$ & $47,143.1$ & $73,036.2$ & $67, .8$ \\
\hline Mexico & $8,478.4$ & $9,121.2$ & $11,265.5$ & 32.9 \\
\hline New Zealand & $3,391.0$ & $5,048.0$ & 6014 & 77.4 \\
\hline Nigeria & $5,614.8$ & $4,706.0$ & $18,319.5$ & 226.3 \\
\hline Norway & $18,585.0$ & $19,255.0$ & $21,154.0$ & 13.8 \\
\hline Russia & $28,949.6$ & $33,303.7$ & $37,712.2$ & 30.3 \\
\hline Singapore & $47,512.4$ & $82,831.6$ & $104,166.4$ & 119.2 \\
\hline South Africa & $6,362.3$ & $5,640.7$ & $5,627.2$ & -11.6 \\
\hline
\end{tabular}

Source: UNCTADSTAT

https://unctadstat.unctad.org/wds/TableViewer/tableView.aspx?Reportld=158358

The mechanics of the B2C and B2B methods are described in Sections I.B and I.C, respectively.

\section{B. Business-to-Consumer Imported Digital Services}

In administering the VAT on business-to-consumer (B2C) supplies of imported digital services, many countries require non-resident businesses to register, charge, and remit VAT on their supplies (e.g., sales) of services to the country where the consumers are located. ${ }^{11}$ Over 60 countries have applied this vendor collection method to collecting VAT on supplies to final consumers. ${ }^{12}$ In applying the vendor collection method, tax agencies need to: (1) establish a workable definition for the scope of the regime; (2) provide simplified methods for non-resident businesses to register, charge, and pay VAT in the importing country; and, (3) put in place effective methods for identifying and dealing with non-compliant businesses.

11 As described below, some countries apply a registration threshold below which overseas businesses are not required to charge VAT on their supplies to domestic consumers.

12 An end-consumer may be either an individual consumer or a business that is not registered for the VAT. In some countries, this may also include government entities. 


\section{Scope}

The starting point in applying the vendor collection method to imported digital services is to define the types of services that will be taxed under the regime. On this issue, some countries apply the method to both digitally and non-digitally supplied business-to-consumer services while others restrict it to prescribed types of digital services. ${ }^{13} \mathrm{~A}$ rationale for limiting the regime's scope to digital services is that these services are most likely to be procured for final consumption and account for a large share of total imported services. Over time, the vendor collection model can be extended to other types of services, particularly those performed remotely like consultancy, accounting, and legal services.

Where the VAT on imported services is limited to digital services, a clear definition is needed for those services. Here, some countries have adopted a general definition of digital services. For example, Norway's VAT Act (Section 1-3 j) defines digital services as those "electronic services capable of provision from a remote location which are supplied via the internet or other electronic network and which cannot be obtained without the use of information technology, and where delivery of the services is essentially automated." Other countries, such as Singapore, have supplemented the general definition with a schedule that specifies those services that are included in and excluded from the regime (Box 1). This approach increases certainty and reduces compliance costs for taxpayers by providing clear guidance as to what is liable to VAT. Appendix 2 provides an example of how this approach works in practice.

\section{BOX 1. Singapore: Examples of Digital Services}

The $7^{\text {th }}$ Schedule of Singapore's GST Act provide positive and negative lists of the activities that are included in or excluded from the definition of digital services, respectively.

\section{Included (positive list)}

- Digital content (e.g. downloading of mobile applications, e-books, and movies) and online subscription-based media (e.g. news, magazines, streaming of TV shows and music, and online gaming);

- Software programs (e.g. downloading of software, drivers, website filters and firewalls);

- Electronic data management (e.g. website hosting, online data warehousing, file-sharing and cloud storage services); and,

- Support services performed via electronic means, to arrange or facilitate a transaction, which may not be digital in nature (e.g. commission, listing fees and service charges).

\section{Excluded (negative list)}

- Services that are currently zero-rated (via exclusion list) or exempt to maintain parity with equivalent services provided by local suppliers. For example, international telecommunication services and advertising services substantially promulgated outside Singapore

- Services that are supplied electronically but contain a significant human effort are not considered to be digital services.

13 Australia and New Zealand apply the VAT to all imported services while Norway, Singapore, and the European Union apply the tax only to digital services. With effect from January 1, 2023, Singapore will extend its GST to B2C imported non-digital services (as well as to imported low-value goods) through the extension of the vendor collection method (referred to as the overseas vendor registration regime in Singapore).

\section{CInternational Monetary Fund. Not for Redistribution}


Digital services and other types of services that can be delivered remotely present challenges to determining the place of taxation. For these types of services, the general approach is to give taxing rights to the jurisdiction where the final consumer has its usual residence. ${ }^{14}$ Accordingly, the non-resident supplier is required to charge the VAT of the final consumer's country and remit the revenue to that country. Applying this approach requires workable rules that a non-resident supplier can use to determine whether the customer is a final consumer and, if so, the consumer's usual place of residence.

The VAT legislation commonly allows a non-resident supplier to presume that the purchaser is a final consumer if the purchaser has a residential address in the importing country and has not provided their VAT registration information. Penalties can apply to purchasers who misrepresent their VAT status in order to avoid the tax.

Non-resident suppliers can use payment, residence, and access proxies to determine the consumer's usual country of residence and apply that country's VAT to the transaction. Some countries' legislation stipulates that two pieces of non-contradictory evidence must be obtained by the supplier to determine the residence, while other countries require the supplier to act reasonably in reaching a conclusion. Evidence of a payment proxy would include information from the credit card or bank account used for payment or location related data from third party payment intermediaries. Evidence of a residence proxy would include the billing or home address supplied in the order. Evidence of an access proxy would include the IP address, mobile telephone country code of the SIM card used, location of the purchaser's fixed telephone landline. Box 2 provides an example from Singapore on the practical application of the proxies to determining a consumer's status. As can be seen in the example, the country of usual residence (and, hence, the country whose VAT is applied) is not necessarily the same as the country where the digital services have been consumed.

\section{BOX 2. Applying Proxy Indicators to Determine a Consumer's Status}

- An Australian resident visiting Singapore purchases and downloads a movie digitally from overseas Company A, which is registered in Singapore's vendor collection system.

- The customer's IP address (access proxy) indicates that he belongs in Singapore.

- But the customer's billing address (residence proxy) indicates that he belongs in Australia which matches with credit card information (payment proxy) provided.

- Company A concludes that the customer belongs in Australia and does not charge Singapore's GST on the sale of the movie.

Correct application of the proxies may be verified during an audit. Overseas suppliers registered under the imported services regime are required to maintain customer information to substantiate VAT collected from all supplies made to their customers in the importing country. In the course of audit, the tax administration can require the overseas suppliers to explain their method of determining the customer's status and to furnish customer information in relation to the imported supplies. This will help verify if the overseas suppliers have applied the proxy indicators correctly.

14 In contrast, services that are physically performed and consumed at the same time and place are generally taxed by the country in which the supply is performed. For example, hairstyling, restaurant, and accommodation services. 


\section{Registration, Filing, Payment}

\section{Registration}

The registration requirements are another key design feature for the vendor collection method. Here, a non-resident business is required to register in those foreign jurisdictions where their supplies of taxable digital services to final consumers have exceeded or are expected to exceed a prescribed amount in a 12-month period-often equivalent to the threshold for domestic VAT registration. Some countries (e.g., Singapore) supplement the general registration threshold with a worldwide turnover test. The intention of this test is to limit registration to major corporations who are making sufficient sales in the country and are presumed to have the capacity to cope with the obligations of the VAT on imported digital services. In contrast, the European Union (EU) does not provide a registration threshold for non-EU suppliers. ${ }^{15}$

Marketplace suppliers are commonly required to register and collect VAT both for their own supplies and those of other suppliers who make sales through the marketplace. ${ }^{16}$ Marketplaces like Amazon and Netflix (also referred to as electronic distribution platforms, electronic interfaces, or digital platforms) can be defined as those internet-based businesses that carry out the functions of authorizing the charge to the customer, authorizing the delivery of the supply to the customer, setting the terms and conditions under which the supply is made, and presenting itself as making the supply. These entities must add together both their own sales of services and those of their underlying suppliers in determining their registration obligations. ${ }^{17}$ As an exception, supplies made through a marketplace by a supplier located in one country to a consumer in the same country are not the responsibility of the marketplace but instead are generally dealt with according to normal domestic VAT rules. ${ }^{18}$

Inclusion of marketplaces in the system greatly increases the efficiency and effectiveness of the vendor collection regime. The requirement for marketplaces to account for VAT for their underlying suppliers significantly reduces the number of registrants and eliminates the temptation for suppliers to split their businesses to stay under the country's registration threshold. As such, revenue administrations can focus administration on a smaller number of registrants. Further, marketplaces maintain sophisticated commercial operations and accounting systems that put them in a better position to comply with the requirements of the vendor collection method then their underlying suppliers.

The vendor collection method typically provides simplified registration procedures and information requirements for non-resident businesses. As discussed below, the simplified approach does not allow non-resident businesses to claim input tax credits in respect of their supplies purchased in the importing country, but only enables them to charge and remit the VAT payable on

15 There is an EUR 10,000 threshold for intra-EU supplies. Intra-EU supplies below this threshold may remain subject to VAT in the Member State where the taxable person supplying the (digital) services is established instead of the Member State where the final consumer is located.

16 In this sense, the marketplace becomes the "deemed" supplier for its underlying suppliers and, as such, is accountable for VAT on all supplies transacted through their platform.

17 The underlying suppliers count only those supplies that they transact directly with consumers (i.e., those services not intermediated by a marketplace) when determining if they must register.

18 In Singapore, local suppliers and marketplaces can agree that the latter will account for GST for the former, subject to approval from the country's Comptroller. 
its supplies (sales) of imported digital services to that country. ${ }^{19}$ Consequently, the vendor collection method does not permit a non-resident to claim a VAT refund if its taxable purchases from that country exceed its sales; nevertheless, the non-resident supplier has the option to register in the standard VAT of that country if it has input tax credits that it wishes to claim. With no risk of refund fraud, tax agencies can reduce the registration information requirements and relax the documentary proofs of identity. An example of a simplified registration form is provided in Section III.D (Figure 3).

\section{Filing and Payment}

The VAT filing procedures for non-resident suppliers of cross-border services are simplified to minimize administrative and compliance costs. Filing frequency is commonly on a quarterly basis, though it can also be monthly, particularly for larger taxpayers. The VAT tax return normally requires non-residents to report only total taxable supplies of digital services and the VAT charged on those supplies. An example of a simplified VAT return is provided in Section III.D (Figure 4).

The time at which the non-resident supplier becomes liable for VAT is typically based on accrual accounting principles. As such, the liability arises at the earliest of the time the payment for the supply is received or an invoice is issued. For example, if the payment for a supply is made on January 30 but the supply is not delivered until February 1 the VAT on the supplier would be required to account for the VAT in January. Timing rules are required to ensure that sales dates are not manipulated to defer the payment of VAT. In this regard, the filing and accounting rules are supported by requiring the non-resident supplier to maintain normal records of account for a period of five years or more in some cases. Detailed tax invoices are not required since the supplies are made to final consumers who cannot claim a credit and, therefore, do not require a tax invoice to substantiate a credit.

Payment of VAT is due at the same time as the simplified VAT return and made as easy as possible by allowing a range of commercial payment options. These include Swift transfer, PayPal, Western Union, and credit/debit cards. An example of a payment form is presented in Section III.D (Figure 5).

Foreign currency exchange rules are applied to ensure that transaction values are not manipulated. Revenue administrations should require acceptable conversion rates to be used and specify when those rates are to be applied or allow the supplier to elect a consistent time from the rates to apply. Options could include the time of supply; the end of the taxable period; or the time of filing the VAT tax return.

19 If a non-resident supplier has input tax credits that it wishes to claim, for example due to having a branch located inside the importing country, it has the option to register in the standard VAT system of that country. In this circumstance, the normal amount of registration information would need to be reported to the revenue administration but, being a foreign entity, the supplier may be subject to additional checks to verify its legitimacy. 


\section{Compliance Strategy}

International experience has demonstrated that most non-resident businesses, particularly the larger ones, voluntarily comply with their obligations under the vendor collection model. ${ }^{20}$ Nevertheless, it is essential to "backstop" voluntary compliance with a comprehensive strategy for addressing noncompliance. Such a strategy should include methods for identifying and dealing with the main compliance risks, including those involving failure to register, failure to file and pay on time and in full, and failure to accurately report the amount of VAT due.

Registration compliance begins with active industry liaison. The importation of digital services to final consumers is dominated by a relatively small number of corporations, particularly large marketplaces and large corporations whose brands are sufficiently established to be sold directly to consumers without requiring intermediation by a marketplace. Liaison with these major players, for example by asking them to identify their competitors in the online markets, will help ensure that all major suppliers have been identified. Repeating this approach with subsequent nominees would help identify the second tier of players.

Third-party data access is crucial to identifying potential registrants. Such data sources include industry analysis reports on particular sectors, financial data (including data from payment services providers showing destination of overseas payments) and lists of registrants in the imported services regime of other revenue administrations (Box 3). This is particularly necessary given that periods of economic adjustment can see a rapid and dramatic reshaping of the marketplace such as has occurred during the recent (pandemic-induced) economic downturn which saw some digital suppliers' business boom. ${ }^{21}$

\section{BOX 3. Third-Party Data Sources}

The third-party data sources can include:

- Information from banks and financial institutions about transfers of funds to offshore entities can identify the larger targets of fund outflows. This information is obtained using the tax administration's powers to require entities to report information relevant for the purposes of administering the tax system.

- Many countries have established agencies to monitor financial flows in and out of the country whose assistance may be obtained if they have the necessary capacity. For example, the Australian Taxation Office has a formal arrangement to source information from the Australian Transaction Reports and Analysis Centre (AUSTRAC) which includes transaction reports for all PayPal-enabled transactions. A simple search by entity name can usually source both aggregated and transaction-level data for a non-resident supplier to which PayPal-enabled payments were made.

20 Australia, New Zealand, Norway, and Singapore have found that most of the overseas vendors have voluntarily complied with their registration, filing, and payment obligations. This is likely to have resulted from the introduction of a registration threshold and the tax agencies' active outreach efforts

21 On this issue, it should be noted that EU members have recently agreed to amend the directive on administrative cooperation (DAC 7) that would require marketplaces to report the income earned by sellers of goods and services who make use of their platforms.. Marketplaces can report this information to a tax authority in a single member state, which will in turn exchange the information with its counterparts throughout the EU as appropriate. The new rules are expected to apply from January 1, 2023. 
- Some countries, for example Japan and Russia, have published publicly accessible lists of registrants and many of these registrants will be doing business in other countries.

- Companies such as Alexa and SimilarWeb can be employed to provide data and conduct analysis of the internet traffic with a country. This data relates to the number of "visits" made to a website and accordingly are relied on since they represent the most popular websites and therefore would be potential registrants.

- Exchange of Information requests can be made of other tax administrations under either relevant tax treaties or the OECD Multilateral Convention on Mutual Assistance in Tax Matters where countries are signatories.

Filing compliance can be enforced by authorizing the revenue administration to issue default assessments of VAT when a supplier fails to file a tax return within the statutory time limit. Such powers allow the revenue administration to make a reasonable estimation of the VAT liability owing. The estimates can be made based on information from previous filings or third-party information from, for example, payment services providers. Once the default assessment has established the tax liability, the revenue administration can then enforce its collection using the methods described below. In this connection, the legal framework should vest the tax administration with the authority to apply "reasonable methods" to assess VAT when a taxpayer fails to file a tax return and not require a more time-consuming audit in determining the tax due. Where such authorities already exist, they should be applicable to VAT owing on account of imported digital services.

Payment compliance: a range of collection enforcement measures can be applied to recover tax arrears. Where a non-resident business fails to fully pay its VAT liability, the revenue administration should be authorized to require financial institutions and other businesses in its jurisdiction to stop paying monies owed to the business and instead transfer the payment to the revenue administration in satisfaction of the tax debt. Also, where available, a request could be made under the Convention on Mutual Administrative Assistance in Tax Matters to the country in which the non-resident business is based for their assistance in collecting the outstanding amounts, to the extent that the country is a signatory to the convention. ${ }^{22}$

A few countries require non-resident suppliers to post a security bond as a condition for registering in their VAT system. ${ }^{23}$ In such cases, the value of the bond may be calculated as a percentage (e.g., 25 percent) of the estimated annual VAT liability of the supplier. While a security deposit can be useful where a supplier may be suspected of seeking to operate in a country for only a period of time before leaving without fully paying its tax liabilities, it is questionable whether such security is necessary for suppliers of imported digital services to consumers. These suppliers typically seek an enduring and growing market share in each country. Their future revenue flows, therefore, will generally remain available for the tax administration to seize in satisfaction of outstanding tax liabilities.

22141 jurisdictions currently participate in the Convention.

23 For example, Belgium, Canada, and Luxembourg. 
Reporting compliance: under-reported VAT liabilities can be detected by:

- Requiring the supplier to provide copies of their books of account for the period being reviewed and for those books to be audited; ${ }^{24}$

- Accessing third party data sources, such as payment systems data, industry sector analysis, observations from other revenue administrations, and social media reports; $; 2$ and,

- Using "secret shopper" purchasing to test whether the non-resident supplier is correctly determining the customers' status (i.e., a final consumer subject to the tax or a registered business not subject to the tax) and making the right decisions about the taxable status of the supply (i.e., taxable or non-taxable). ${ }^{26}$

A robust penalty system is another crucial element of the compliance strategy. While many digital suppliers are massive corporations unlikely to be affected by the financial impact of a penalty, nevertheless a potentially heavy penalty could badly affect a supplier's reputation in the community. Internationally, penalties range up to 200 percent of the undercharged tax for underreporting of taxable supplies through to fines and imprisonment for willful misrepresentation.

\section{Business-to-Business Imported Digital Services}

In administering the VAT on business-to-business (B2B) supplies of imported digital services, tax administrations commonly require resident businesses to apply the reverse charge method. ${ }^{27}$ This method requires resident businesses that purchase a digital service from a non-resident business to charge the VAT as if it is the supplier. It also allows the resident business to receive an offsetting VAT credit to the extent that it uses the service to produce taxable supplies. In most countries, the reverse charge method applies to all types of imported services, both digital and non-digital.

The reverse charge can be required for all supplies of imported digital services or only those where the charge is not fully claimable as an input tax credit. Some jurisdictions require a reverse charge to be applied against all imported digital services and then allow input tax credits to be claimed to the extent that the services are used to produce taxable goods or services. To simplify accounting, other jurisdictions require the reverse charge to be applied only if the imported digital

24 Non-resident suppliers are subject to the same information retention and production requirements as apply to domestic VAT payers. The tax administration may also seek the information from a non-resident business's local subsidiary. Failing that, the legislation in some countries (e.g. Australia) prevents a business from producing that information as evidence in any subsequent hearing on the tax assessment (Section 353-25 and 353-30 of Schedule 1 to the Tax Administration Act 1953, Commonwealth of Australia). This can provide strong motivation for non-resident suppliers to cooperate with information requests. As a last resort, most countries have a capacity to geo-block businesses from operating in their country in the event they fail to comply with the country's tax obligations.

25 Third-party data sources can be accessed in a similar manner as described above in respect of registration compliance with one major difference. A tax administration may invoke the Exchange of Information provisions under tax treaties and/or the OECD Multilateral Convention on Mutual Assistance in Tax Matters to ask another signatory country to use its domestic powers to obtain information relevant from one of its residents if the tax administration has already attempted to use its own authorities to obtain the information.

26 The secret shopper may be an authorized official of the tax administration or other government agency.

27 The reverse charge mechanism for cross-border services has been adopted by many countries. Refer to KPMG VAT treatment of cross-border services 2017 survey at https://home.kpmg/bg/en/home/insights/2017/11/vatand-gst-treatment-of-cross-border-services.html. See also the OECD's Consumption Tax Trends 2020 at https://www.oecd-ilibrary.org/taxation/consumption-tax-trends-2020 152def2d-en 
services are not fully creditable. In such cases, either no input tax credit or only a partial credit can be claimed depending on the extent to which the services are used to produce taxable goods or services. Both methods achieve the same tax outcome.

The reverse charge results in tax being paid where the resident business uses the imported digital services to create non-creditable or only partially creditable supplies. Where the imported supply is used in creating a non-taxable supply, such as a financial supply, the resident business will not be permitted to claim an input tax credit for the purchase and, as a consequence, VAT will be payable by that business. Similarly, if the imported digital service is used partly to produce a taxable good or service and partly to produce a non-taxable good or service, the input tax credit can be claimed only for the taxable supply and, therefore, some VAT will be payable on its non-taxable supplies. Finally, if a business imports a digital service for private consumption or partially for private consumption, then it would not be entitled to a full input tax credit on the purchase and, again, some or all of the VAT would be payable.

Resident businesses report the reverse charge on the standard VAT tax return. In most countries, businesses report the value of imported services (digital and non-digital) subject to the reverse charge, the amount of output tax to be accounted for on the imported services, and the amount of input tax claimable on account of the imported services in the same fields of the VAT return that apply to all transactions. That is, countries usually do not create a special tax return for reverse charge supplies nor do they adjust the VAT return to include separate fields for reporting those supplies. 


\section{ADMINISTERING THE VAT ON LOW-VALUE IMPORTED GOODS}

\section{A. Challenges}

Many countries provide a de minimis exemption for which no or low VAT is applied on imported goods whose value is below a prescribed threshold. Such treatment has been designed to simplify administration and introduced at a time when internet shopping did not exist and the level of imports benefitting from the relief was relatively small. However, with the boom in cross-border on-line sales ${ }^{28}$, some governments have become concerned that the low-value exemption has led to material amounts of lost VAT revenue. They also worry that the exemption puts domestic retailers (who charge VAT) at a competitive disadvantage compared to non-resident suppliers (who are exempted from charging VAT) on the same low-value goods.

To address those concerns, some countries ${ }^{29}$ now require prescribed non-resident businesses to charge VAT on their supplies of low-value imported goods to final consumers and remit the revenue to the importing country. In doing so, and to address collection costs typically associated with the traditional customs collection model, these countries have adopted the simplified methods under the vendor collection model described in Section I. These countries have also combined this reform with methods for accelerating the release of the goods at customs where they are subject to a vendor collection model for VAT. The vendor collection method applies to goods that are only subject to the VAT on importation, which typically are limited to goods with a value below the customs duty de minimis value and exclude goods that are subject to excise tax.

By collecting the tax from suppliers upstream at the point of sale, the vendor collection model provides a highly cost-effective way of administering the VAT on low-value imported goods. At the same time, the de minimis exemption still applies to those small non-resident businesses whose supply of low-value goods is below a prescribed ceiling as described further below. In this way, the vendor collection model is likely to capture a substantial proportion of imported low-value goods at very low administrative costs. ${ }^{30}$

28 Evidence on the surge in low-value imported goods can be inferred from data on cross-border supplies of business-to-consumer merchandise exports and the number of international parcels with the latter a proxy for low-value shipments. Cross-border supplies of business-to-consumer merchandise exports are estimated to have increased rapidly from US\$ 189 billion in 2015 to US\$ 412 billion in 2018 (source: UNCTAD Digital Economy/Information Economy Reports, 2015, 2017, 2019). During the same period, the number of international parcels also increased sharply from 115.1 million units to 191.8 million units (source: Universal Postal Union Postal Economic Outlook, various issues).

29 For example, Australia (2018), New Zealand (2019), Norway (2020) and the United Kingdom (January 2021). The European Union is expected to introduce the same reform in July 2021 and Singapore in January 2023.

30 The policy arguments for reducing or eliminating the de minimis exemption are described in The Optimal Threshold for GST on Imported Goods by J. Creedy (Australian Economic Review, vol. 50, no. 2, June 2017, pp. 169-80). 


\section{B. Administrative Procedures}

\section{Registration, Filing, and Payment}

The low-value imported goods (LVIG) regime provides a registration threshold for businesses and a ceiling for goods subject to the regime. As described below, non-resident businesses with supplies of low-value imported goods above the registration threshold are required to charge, collect, and remit VAT to the importing country for those goods valued below the ceiling.

The registration threshold, where applicable, ensures that only larger businesses are subject to the LVIG regime. This threshold should be consistent with the domestic threshold to ensure there is no discrimination against foreign suppliers. ${ }^{31}$ Generally, only B2C low-value imported goods are counted against the registration threshold; higher-value B2C supplies and all B2B supplies are excluded. This is because the regime is intended to apply only to final consumers' purchases of low-value imported goods. The LVIG regime typically applies the same registration procedures and registration form that are used by the imported digital services scheme described in Section I.

The registration threshold applies to the aggregate of low-value imported goods and imported digital services. Where a non-resident makes supplies of both imported digital services and lowvalue imported goods, the two sets of supplies would be added together and applied against the registration threshold. If the combined supplies exceed the threshold, the non-resident would be required to charge VAT on both its imported digital services and low-valued goods, even if separately the supplies of imported digital services and low-valued imported goods fall below the threshold.

The LVIG regime applies VAT to those imports made to final consumers ${ }^{32}$ whose value is below a prescribed ceiling. If the value of the imported goods is below the ceiling then the nonresident supplier will be required to charge and collect the VAT prior to importation. If the value of the imported goods is above the ceiling then VAT would be charged and collected by the customs department upon importation based on standard customs procedures. The regime applies only to B2C supplies of low-value-imported goods; B2B supplies are generally excluded and subject to VAT at import. ${ }^{33}$

Supplies of low-value imported goods by non-resident suppliers whose supplies fall below the registration threshold are not subject to VAT. In such cases, VAT would be applied by neither the LVIG regime nor the customs department. This is a practical concession to simplification because there is no realistic alternative to collecting the VAT on such supplies since the option of requiring consumers to self-declare the VAT has proven unworkable in many countries. This concession would result in negligible losses of revenue since the overwhelmingly largest portion of low-value imported goods are supplied by very large businesses (including marketplaces) who would be required to register for the LVIG regime. While small non-resident businesses may find the concession creates

31 The LVIG regimes in Australia, New Zealand, and Norway include a registration threshold. The EU and UK regimes do not include a threshold.

32 Final consumers are defined to be individual consumers and businesses not registered for VAT.

33 B2C comprises supplies by individual consumers and business not registered for VAT; B2B comprises supplies to businesses registered for VAT. To simplify administration, some countries allow non-resident vendors to charge VAT on their B2B supplies in the event that they make both B2B and B2C supplies. For example, New Zealand provides this election to those non-resident suppliers whose B2B supplies are less than 50 percent of total supplies (so predominantly sell B2C). In such cases, the non-resident supplier must provide a full tax invoice, which allows the GST registered recipient to claim an input tax deduction on the supply. 
an incentive to make supplies directly to consumers instead of through a marketplace, this incentive may be offset by the large marketing and logistical benefits that marketplaces provide to their underlying suppliers.

As with the imported digital services regime, the LVIG regime also needs to provide suppliers with criteria for determining whether the purchaser of a low-value imported good is a final consumer belonging to the importing country. The legislation typically permits the overseas supplier to presume that the customer is a final consumer unless they have provided a VAT registration number or otherwise notified the supplier that they are a VAT registrant. There is no requirement for the supplier to validate the information. Unlike the imported digital services regime, the LVIG system does not have the ambiguity in determining whether the final consumer belongs to the importing country since if a physical product is delivered to a country, the place of supply for VAT purposes is in that country.

Simplified filing and payment systems should also be adopted. To reduce compliance and administrative costs, the same filing and payment periods should be applied to both the LVIG and imported digital services regimes. Similarly, the same VAT tax return for imported services can be used by adding fields for reporting the value of the imported digital goods and the associated VAT charged (refer to Section III.D, Figure 4). As with supplies of imported services, if credits occur in the LVIG supplier's VAT accounts due to reversals or errors, these can be offset in future period tax returns instead of by issuing same period refunds (this is also illustrated in Section III.D, Figure 4). As mentioned earlier, the vendor collection method does not permit non-resident suppliers to claim credit for VAT paid on any purchases from the importing country, but retain the option for registering under the importing country's standard VAT regime if they wish to claim credit for any VAT paid on such purchases.

\section{Leveraging Marketplace Suppliers}

The maturation of the global internet-based sales network and its concentration into a small number of marketplace suppliers provides an administrable population of suppliers to tax.

The technological innovation that has occurred in the sale, payment and delivery systems has seen a massive increase in the value of LVIGs being ordered through the internet. It has been estimated that two-thirds of cross-border supplies of goods are through marketplace platforms (e.g., Amazon, Alibaba) with more than half transacted through only three platforms. ${ }^{34}$ Their inclusion in the definition of supplier, as described below, has allowed jurisdictions to achieve widespread administrative coverage of this rapidly growing market with a still manageable number of businesses - up to 1,000 entities.

Under the LVIG regime, the taxable person is the supplier defined to be either the vendor or an electronic marketplace that intermediates the supply. The legislation should define the conditions under which the marketplaces are deemed to be the supplier for businesses trading on their platforms (refer to Section III.B and Appendix 3). Marketplaces have potential to enhance significantly the compliance of their underlying suppliers since these supplies are transacted by the marketplace who would be aware of the true price charged and have little incentive to undervalue the supply since their commission is based on the actual sales price.

34 Source: Cross-border E-Commerce Shopper Survey 2017 by International Post Corporation. The survey was based on 28,892 cross-border consumers from 31 countries. The three largest platforms are Alibaba, Amazon, and eBay. 
Other intermediaries are generally outside the scope of the LVIG regime. For example, postal operators, express carriers, and fulfillment centers are not considered to be suppliers (like vendors and marketplaces) and, therefore, have no responsibilities in collecting the VAT under the vendor collection method. ${ }^{35}$ As an exception, both Australia and New Zealand's regimes include so-called re-deliverers who provide shopping services or an alternative offshore mailbox service for customers. ${ }^{36}$ Re-deliverers are subject to the LVIG regime because their activities result in neither the vendor nor the marketplace knowing the final location of the supply, which could escape the VAT if the re-deliverers were not included in the system. ${ }^{37}$

\section{Compliance strategy}

The LVIG regime applies similar methods to those for the imported digital services regime in ensuring non-resident suppliers comply with their VAT registration, filing, payment, and reporting obligations. Three additional methods involve re-deliverers, cross-checking payment information, and leveraging customs controls to identify under-valued or misclassified imports.

The re-deliverer industry requires a special focus on identifying potential registrants and establishing those who fail to register for VAT. The studied countries reported that re-deliverers tend to establish themselves in countries that are part of the prevalent trade routes into a country so they can use established transport links and relationships with customers and suppliers. The re-deliverer industry exists to allow citizens of a country to order products from an overseas supplier and nominate the re-deliverer as the delivery address for the product. The re-deliverer then forwards the product to the actual address of the citizen. Re-deliverers therefore have to advertise and operate in plain sight and can therefore generally be identified through internet research and industry liaison.

\section{Cross-checking tax and customs administration information plays an important role in} ensuring payment compliance. To this end, the customs administration should prepare a monthly listing containing the total value of imports of low-value goods declared in the importing country for each supplier participating in the LVIG regime. The aggregated monthly listings should be made available to the tax authorities who, in turn, will compare the total value of the transactions declared upon importation with the VAT returns submitted under the LVIG regime. This will allow the tax administration to identify any discrepancies between the amount of VAT that the supplier reported to customs as having been paid at the point of sale and the amount that the supplier actually paid to the tax administration. Similar information exchanges can help identify those non-resident suppliers who have failed to register for the LVIG regime despite meeting the registration requirements.

35 Postal operators, express carriers, agents, and other persons who carry out customs formalities for non-resident suppliers should report the supplier's VAT identification number in the import declaration so that the VAT is not paid again to customs when the goods are imported. The supplier is responsible for providing these persons with their identification number. This issue is discussed further in Section II.C.

36 An offshore mailbox service generally describes a service where, for a fee, a company provides a delivery address in a country that a customer can use to have deliveries made to for subsequent reshipping to their home country. This service can be used to bypass license agreements, for example, that restrict the ability of the customer to buy certain products from anyone other than the license holder. Some consumers use a re-deliverer in another country to purchase a product at a lower price than in the domestic market. As such, the re-deliverer should be deemed to be a supplier (like a vendor or a marketplace) and required to register and charge VAT under the vendor collection method (if they meet the registration threshold, where applicable).

37 As a special arrangement, the EU's LVIG regime permits sellers and marketplaces the option to pass the import VAT collections to postal operators, express carriers, and customs agents. Refer to Appendix 1. 
The interaction between the VAT and customs procedures provides an effective mechanism to manage reporting risk. As mentioned earlier, online marketplaces greatly reduce the scope for undervaluation by their underlying suppliers. Nevertheless, there remains the risk that overseas suppliers who make direct sales to final consumers (without marketplace intermediation) may undervalue their supplies to gain a competitive advantage. There is also a risk that offshore suppliers not registered for VAT may undervalue a consignment below the LVIG threshold and therefore avoid legal liability for VAT. Tax and customs administrations can mitigate these risks by adopting a compliance program based on:

- Third-party information (refer to Box 3).

- Risk profiling, monitoring past trading behaviors, intelligence assessments and referrals from industry.

- X-ray imaging combined with artificial intelligence interpretation can be used to scan packages and determine whether the images of their contents are consistent with those for low-value goods.

- Though at an early stage, blockchain technology could enable an intermediary in the supply chain to collect VAT on behalf of the governments, potentially allowing taxes to be automatically transferred to the government using smart contracts. ${ }^{38}$

\section{Coordination with Customs}

LVIG must pass through customs to enter the country; therefore, integration with the customs regime is crucial. Integration must occur over the types of goods included and excluded from the regime, the value range within which LVIG will apply, and the treatment of LVIG goods as they go through customs.

The VAT LVIG regime should not conflict with the customs duty regime. Generally, to leave customs procedures undisturbed, the LVIG regime applies to all imported goods whose value is equal to or lower than the exemption threshold for customs duties. The normal customs procedures apply to those importations valued above this threshold. Similarly, the LVIG regime would generally not be applied to excisable goods (e.g., alcohol and tobacco products), which are often subject to customs duties at higher rates. Instead, these importations would be subject to VAT under the standard customs procedures. As mentioned earlier, a supply may not be subject to VAT by the tax administration or customs if the goods are below the customs limit and the offshore supplier is below the registration threshold for the LVIG regime.

The system needs to be designed to avoid double taxation. Double taxation could occur if the non-resident supplier charges VAT under the LVIG regime prior to importation and the customs department charges VAT again upon importation. To prevent this from happening, the non-resident supplier is required to advise customs of the VAT paid status as part of the importation documentation. To this end, the supplier must ensure that the relevant customs documents include: (1) the supplier's VAT registration number and/or other business number and (2) indicate whether VAT was charged previously under the LVIG regime. This information would be fed into the customs cargo system to facilitate quick processing and clearance as shown in Figure 1 (based on Australian Taxation Office practices).

38 Refer to Study Report on Disruptive Technologies, World Customs Organization (June 2019) for a discussion of blockchain technology (page 22), x-ray scanning (pages 74-80), and artificial intelligence (75-80). 
FIGURE 1. Customs Processing of Low-Value Imported Goods ${ }^{39}$

Notification requirements: customs
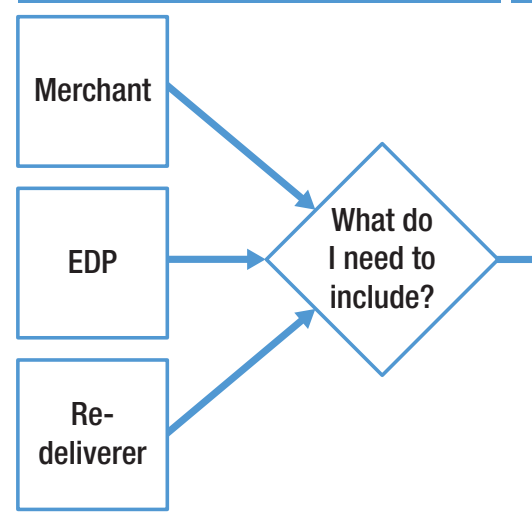

Transporter/customs broker

Registration number of the supplier for GST purposes if applicable

Whether GST was charged

on the supply

if applicable
Border Authority

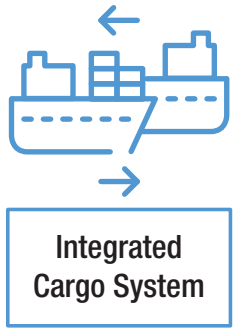

The ABN of the recipient, Integrated
Cargo System

39 As referenced in the figure, "ABN" (Australian Business Number) identifies a business as a GST registrant. The business will not be charged GST if it presents the ABN to the non-resident supplier when making the transaction. "EDP" refers to electronic distribution platform (i.e., a marketplace). 


\section{IMPLEMENTATION TASKS}

\section{A. Implementation Plan}

A comprehensive, timebound implementation plan is crucial to the successful introduction of imported digital services and low-value imported goods regimes. The plan should identify and sequence the key tasks that are to be undertaken by the government, the tax administration, and non-resident businesses. Such a plan ensures that each implementation task is completed in the right order and at the right time to ensure subsequent and dependent tasks proceed smoothly.

International experience has demonstrated that approximately two years is needed to implement the reforms. Figure 2 provides a high-level summary of the implementation plan used by the Australian Taxation Office. As can be seen in the figure, key implementation tasks include conducting extensive industry consultations, deciding on the regimes' key design features, enacting legislative changes, adjusting administrative processes and information systems, and providing taxpayer education and tax officer training. These tasks are elaborated on in the remainder of this section.

\section{B. Legislative Changes}

The purpose and scope of the legislative changes should be designed and agreed. Prior to drafting the legislative changes, Government departments commonly prepare a discussion paper which examines the problems resulting from the current policies governing imported services and low-value-imported goods. This would include an assessment of the revenue loss from untaxed (or under-taxed) importations, the competitive disadvantages faced by resident businesses, and the amount of additional revenue that may be generated by reforming the system. Based on this assessment, the discussion paper would propose the policy changes needed to address the underlying problems.

The value-added tax and customs laws needs to be amended to translate the intended policy objectives into new legislation. As listed in Table 2 below, the amendments include provisions that define the imported services and imported goods subject to the VAT, the persons who will be liable for paying and collecting tax as well as the registration, filing, and payment requirements. Importantly, the primary legislation should be supported by secondary legislation (regulations) and operational guidelines that provide guidance on the practical application of the legislation.

The legislation should clearly define electronic marketplaces and the conditions under which they are deemed to be the supplier for the underlying supplies made through their platforms. This is important because a large volume of sales is transacted by these entities. For this purpose, an "electronic marketplace" can be defined as a marketplace operated by electronic means through which a person (the underlying supplier) makes a remote supply by electronic means through another person (the operator of the marketplace) to a third person (the recipient). As such, the marketplace would be regarded as the supplier if they meet any of the following conditions:

- The marketplace authorizes the charge to the customer;

- The marketplace authorizes the delivery of the supply to the customer;

- The marketplace sets the terms and conditions under which the supply is made 
FIGURE 2. Implementation Plan

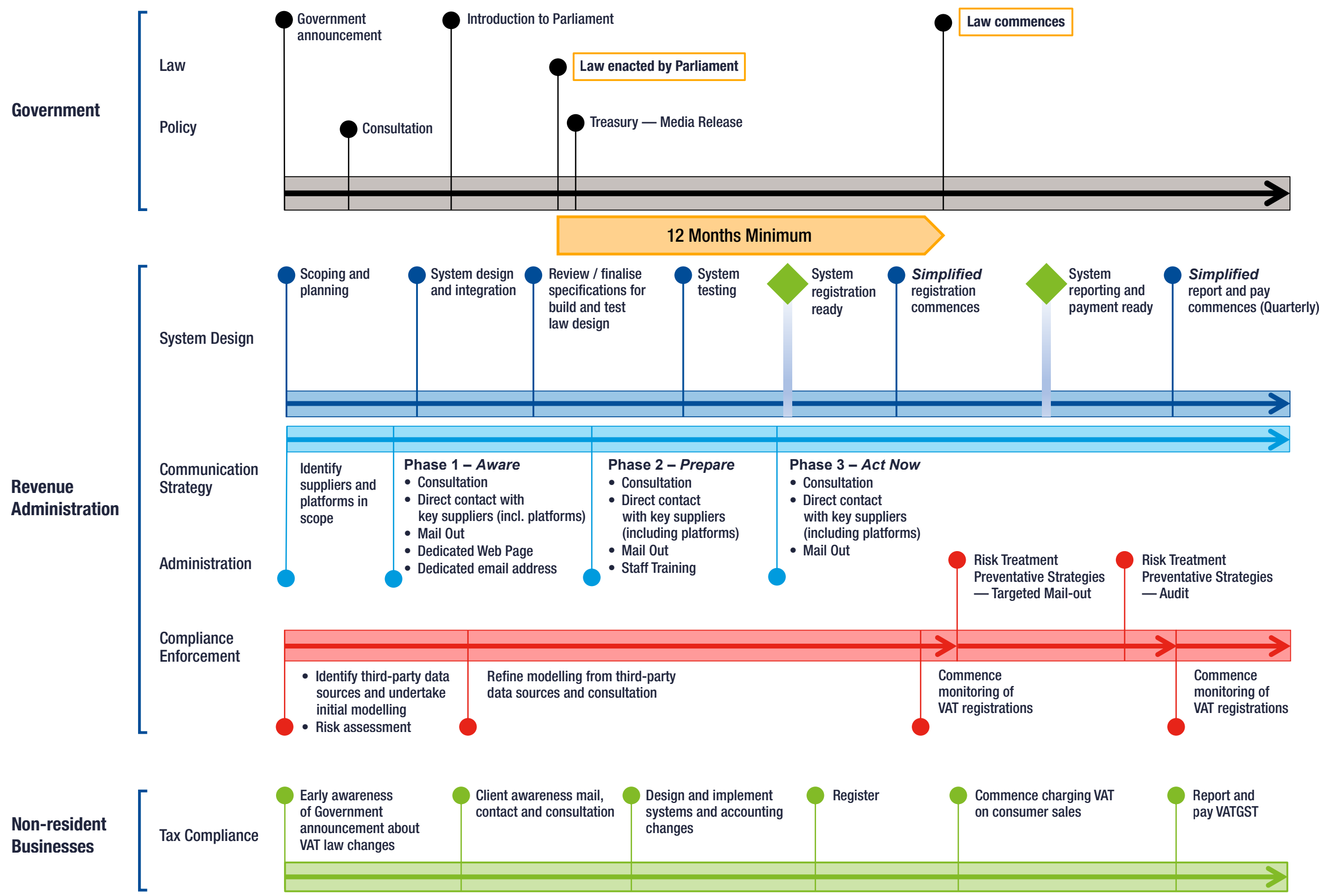


- Documentation issued to the customer identifies the supply as made by the marketplace; and/or,

- The marketplace and merchant contractually agree that the marketplace is responsible for VAT obligations.

Appendix 3 presents an example of applying the above criteria by a supplier of electronic digital services.

\section{TABLE 2. Key Legislative Changes for the Imported Digital Services and Low-Value Imported Regimes}

\begin{tabular}{|c|c|}
\hline IMPORTED DIGITAL SERVICES & LOW-VALUE IMPORTED GOODS \\
\hline $\begin{array}{l}\text { Definition of digital (and other) services that are } \\
\text { subject to tax, supplemented by appropriate place } \\
\text { of taxation rules }\end{array}$ & $\begin{array}{l}\text { Remove the de minimis exemption for non-resident } \\
\text { businesses with supplies that exceed a prescribed } \\
\text { threshold and define the supply of low-value goods } \\
\text { subject to tax. }\end{array}$ \\
\hline $\begin{array}{l}\text { Definition of persons to whom the VAT is charged } \\
\text { (e.g., final consumer). }\end{array}$ & $\begin{array}{l}\text { Definition of persons to whom the VAT is charged } \\
\text { (e.g., final consumer). }\end{array}$ \\
\hline $\begin{array}{l}\text { Definition of taxable persons (e.g., platforms and } \\
\text { vendors). }\end{array}$ & $\begin{array}{l}\text { Definitions of taxable persons (e.g., vendors, platforms, } \\
\text { re-deliverers). }\end{array}$ \\
\hline $\begin{array}{l}\text { Circumstances when the platform or other intermediary } \\
\text { can be deemed as supplier for underlying suppliers that } \\
\text { make supplies on the platform. }\end{array}$ & $\begin{array}{l}\text { Circumstances when the platform or re-deliverer can } \\
\text { be deemed as a supplier for underlying suppliers that } \\
\text { make supplies on the platform or re-deliverer. }\end{array}$ \\
\hline $\begin{array}{l}\text { Simplified registration, filing, and payment processes, } \\
\text { including exchange rate and identification number. }\end{array}$ & $\begin{array}{l}\text { Simplified registration, filing, and payment processes, } \\
\text { including exchange rate and identification number. }\end{array}$ \\
\hline $\begin{array}{l}\text { Establish recordkeeping requirements for non-resident } \\
\text { suppliers. }\end{array}$ & $\begin{array}{l}\text { Establish recordkeeping requirements for non-resident } \\
\text { suppliers. }\end{array}$ \\
\hline $\begin{array}{l}\text { Obligation to use reverse charge either on all } \\
\text { importations by a VAT registered business or on those } \\
\text { importations that will not be able to fully be credited by } \\
\text { that business (if not currently in existence). }\end{array}$ & $\begin{array}{l}\text { Information to be included in importation documents } \\
\text { and information to be provided to customers. }\end{array}$ \\
\hline \multirow[t]{2}{*}{$\begin{array}{l}\text { Penalties, including for consumer misrepresenting as } \\
\text { business. }\end{array}$} & $\begin{array}{l}\text { Penalties, for consumer misrepresenting as a business } \\
\text { (if applicable). }\end{array}$ \\
\hline & $\begin{array}{l}\text { Preserve the customs duty paid on goods above } \\
\text { the LVIG threshold and the excise on excisable goods. } \\
\text { Coordinate with customs processes to avoid double } \\
\text { taxation. }\end{array}$ \\
\hline
\end{tabular}

\section{Consultation and Engagement}

Early and effective consultation is key to obtaining high levels of compliance from nonresident suppliers. This is greatly facilitated where the proposed rules and systems are based on international best practices to increase familiarity of the target audience (mainly large marketplaces) and to avoid requiring them to adopt different practices in different countries.

As a first step, revenue administrations typically conduct industry analysis, liaise with other administrations, and contact industry associations to identify the population of potentially affected companies. They can then contact each company to explain the operation of the new regimes and elicit their feedback on key design features of the regimes. 
Detailed technical and procedural advice should be issued simultaneously with the release of the legislation. This enables the suppliers to quickly understand their obligations and implement the system changes required to meet these obligations. As these regimes are designed specifically for application by foreign suppliers, the guidance and advice should be available in the languages used by the suppliers.

Proactive follow-up is also essential. As part of the consultation process, some tax agencies send a registration form to all potential registrants. These businesses are required either to complete the form or provide an explanation as to the reasons why they do not intend to register. Designated teams are set up to monitor and follow-up with unresponsive entities. A dedicated tax officer (i.e., a key client manager) may be assigned to liaise with the largest businesses and assist them in answering questions and coordinating the resolution of any issues involving the LVIG regime. This helps assure the compliance of those large businesses who will account for the largest portion of revenue.

\section{Administrative Processes and Information Systems} New systems will need to be created to facilitate registration by non-resident businesses. The information requirements and proof of identity can be simplified since the regime requires businesses to report only VAT charged on their sales and does not allow credits to be claimed on purchases. These features reduce the scope for dishonest businesses to register for the purpose of claiming illicit refunds. Simplified registration will also assist in completing the registration formalities from overseas since the form will need to be submitted on-line. It is Important that these systems (and the information needed to navigate them) are available in English where this is not the local language of the taxing jurisdiction.

\section{A simplified registration form can be adopted to support the simplified registration require- ments. Figure 3 provides an example of a simplified registration application with minimal infor- mation requirements as used by the Norwegian Tax Administration. Other jurisdictions, like New Zealand, require additional information, but still less than the standard VAT form (Appendix 4). Non-resident businesses can use the same form to register for both the imported services (including digital services) and low-value-imported goods regimes. This can be seen in the New Zealand form which explicitly asks the business to indicate the regime for which it seeks to register.}


FIGURE 3. Sample Simplified Registration Form

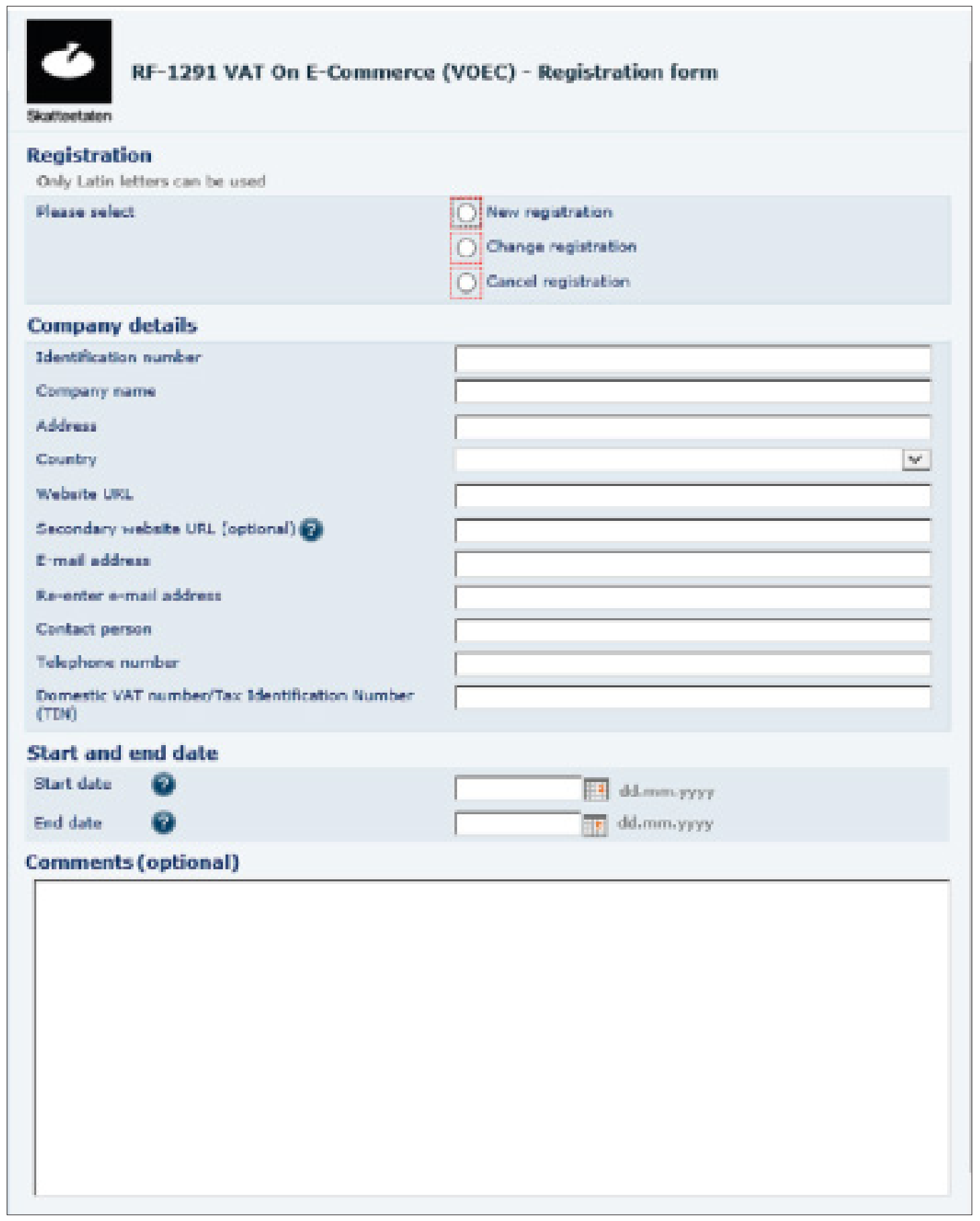

Filing systems also need to be simplified and filed over the internet. Since the regime operates on a 'pay-only' basis, non-resident suppliers are required to report only the amount of VAT due from their taxable sales. Consequently, the VAT return does not need to distinguish between taxable and non-taxable sales as it would on the standard VAT return nor does it require information on the value of VAT paid on purchases since credits are not allowed to be claimed. 
Figure 4 provides an example of a simplified VAT return used by the Norwegian Tax Administration. As can be seen under the form's Sale of goods and services heading, the same simplified return can be used to report VAT for both low-value imported goods and imported digital (electronic) services. ${ }^{40}$

FIGURE 4. Sample Simplified VAT Return

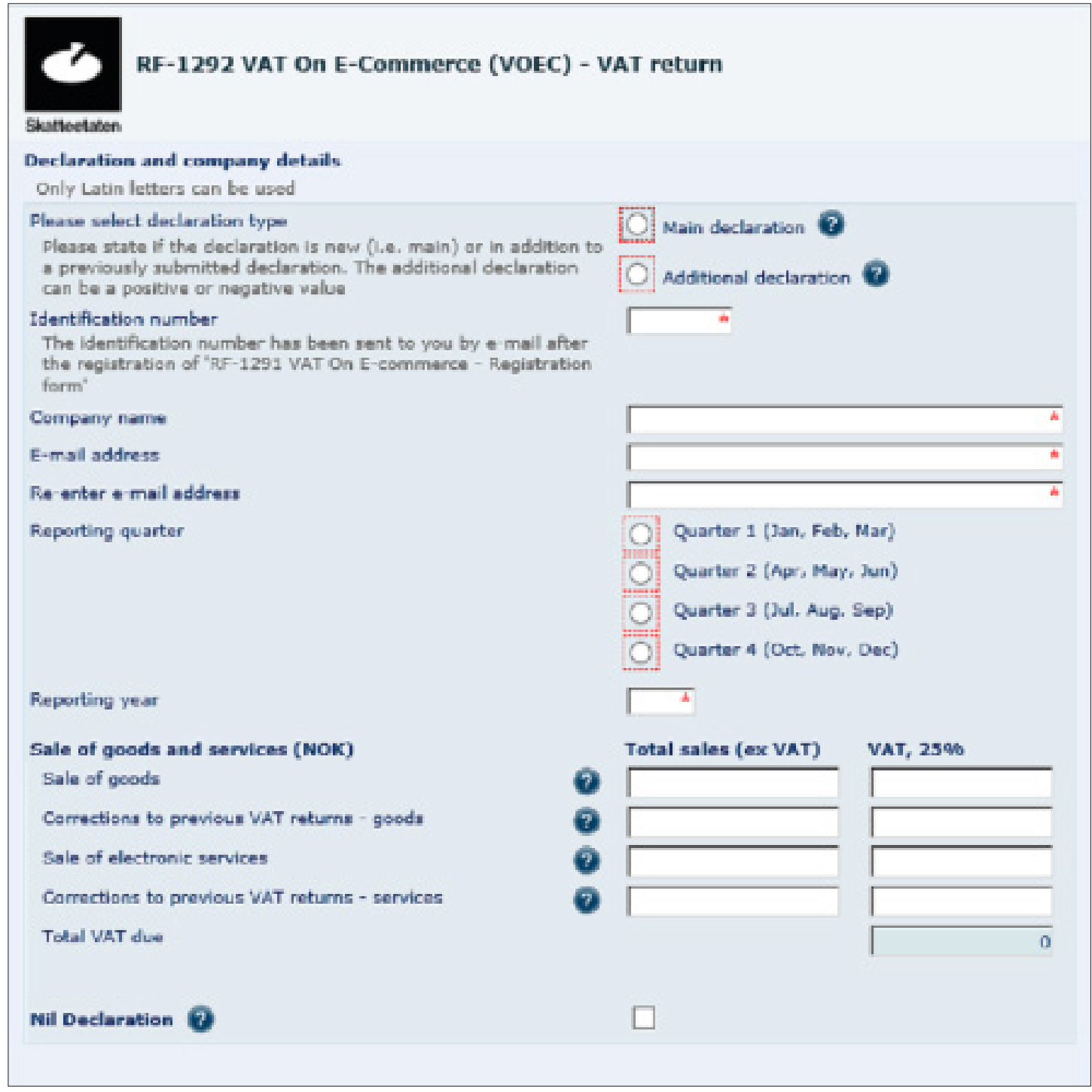

To ease compliance, revenue administrations provide a range of payment options for non-resident suppliers. These may include payment by direct debit, credit card, SWIFT transfer. Figure 5 provides an example of a simplified VAT payment form used by the New Zealand Inland Revenue Department. Like the registration form and tax return, the payment form must be submitted electronically.

40 As mentioned earlier, Norway's regime applies only to digital (electronic) services. 
FIGURE 5. Sample Payment Document

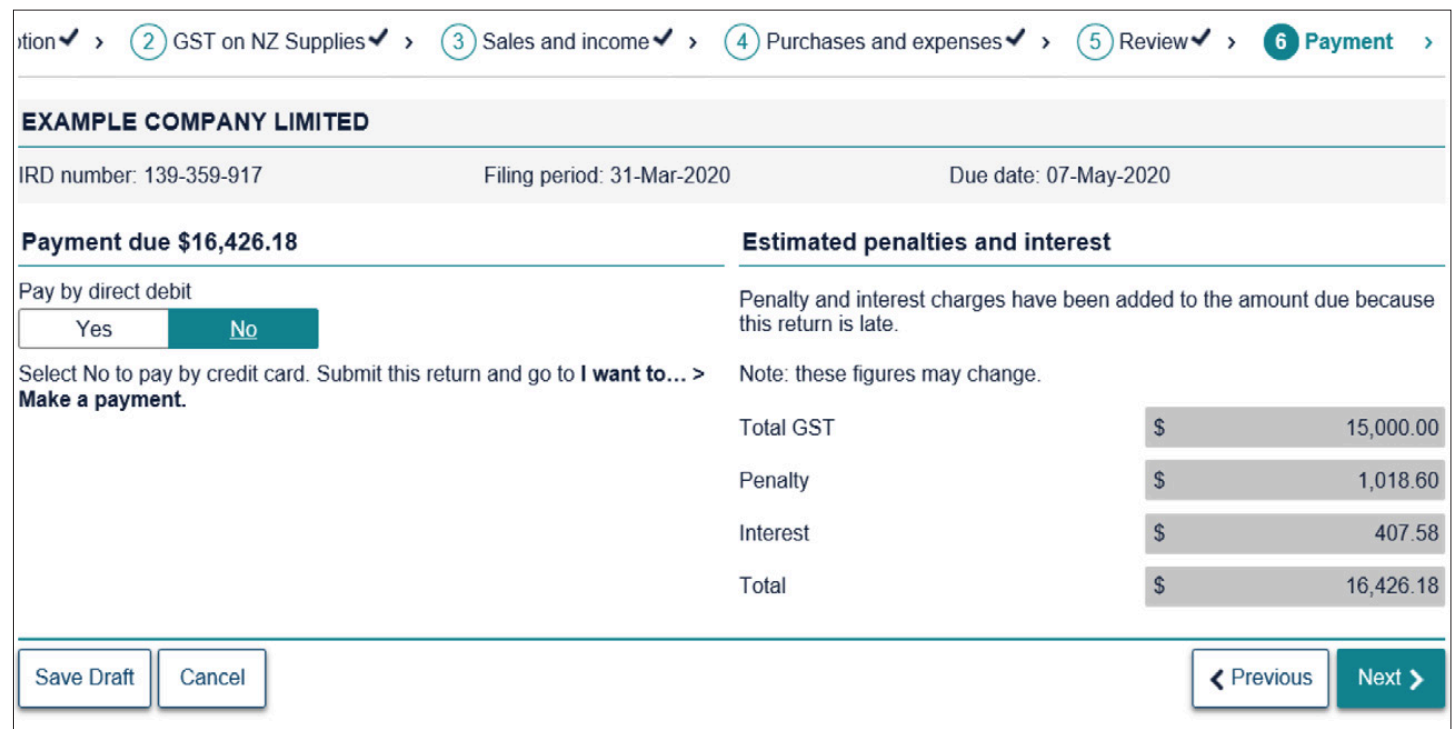

New compliance capability will be needed for administering the digital services and LVIG regimes. To this end, an administrative unit should be established to design and implement a strategy for identifying, assisting, and ensuring the compliance of VAT payers under the two regimes. The unit's responsibilities are set out in Box 4.

\section{BOX 4. Responsibilities for a Compliance Unit}

- Research the internet and third-party data sources to identify the non-resident entities who are supplying digital services and low-value imported goods to the country in excess of that country's registration threshold. In addition to identifying the major platform operators, this unit would also work out how to conduct analysis to identify the significant direct suppliers and re-delivers in major sectors.

- Develop the relationships necessary for liaising with the platform, merchant and redelivery industries to obtain intelligence about compliance problems for the industries and potential compliance gaps in the industries.

- Develop close working relationships with the Customs department operating in that country. Not only will they be a valuable source of intelligence, a smooth operating relationship between the revenue and Customs authorities is necessary to deliver the smooth passage of goods for compliant LVIG suppliers.

- Work with the tax administration's treaty experts to build the protocols under which the administration could obtain help from other administrations on how to set up and operate a digital services and LVIG regime. They would also work with the treaty experts in establishing the protocols under which exchange of information provisions might be lawfully used to obtain information from other administrations under Treaty or Convention provisions. 


\section{E. Taxpayer Education Outreach and Tax Officer Training}

Taxpayer education and assistance programs should be customized to the needs and circumstances of non-resident taxpayers. These programs need to be accessible and delivered remotely through on-line means since the businesses are located offshore. Educational materials should include written guidance, online seminars and video guides, and dedicated website page. ${ }^{41}$ Tax agencies should take the initiative in sending the materials to taxpayers and encouraging them to participate in various training activities. Initially, education and assistance should convey general information about the operation of the new regime and then provide more technical guidance as the implementation date draws closer. The largest businesses should be assigned a dedicated tax officer to serve as the taxpayer's single point of contact for training and assistance purposes.

Tax officers need to fully understand the changes in order to effectively administer the new tax. Training is also required to assist taxpayers in complying with their obligations. In this regard, a tax officer training program will need to be designed, comprising both induction training and special topic training. An initial round of induction training is best targeted on taxpayer services officers and delivered immediately after the government announces its intention to introduce the reforms to assist officers in handling initial enquiries from public. A second, more technical round of training would be delivered near to the implementation date for all staff who administer the VAT.

Taken together, the various tasks described in this section can require up to two years to design and implement. Like any significant tax reform, the time and effort spent on these tasks will ultimately determine the degree of success in implementing the vendor collection model.

41 Some examples of taxpayer educational materials for imported digital services can be found on the Inland Revenue Authority of Singapore's website: https://www.iras.gov.sg/irashome/GST/GST-registered-businesses/ GST-and-Digital-Economy/GST-on-Imported-Services/ 


\section{APPENDIX 1. EUROPEAN UNION DIGITAL SERVICES AND LOW-VALUE IMPORTED GOODS SCHEMES}

Digital Services Scheme. Since 2015, the EU's Mini One Stop Shop (MOSS) has provided a simplified system for non-EU and EU vendors to declare and pay VAT on business-to-consumer supplies of telecommunications, broadcasting and electronic (TBE) services in the EU. ${ }^{42}$ Beginning in July 2021, the MOSS system will be extended to: (1) additional types of B2C services; (2) to intra-Community distance sales ${ }^{43}$ of goods; and (3) certain domestic supplies of goods.

Under this expanded regime, the MOSS system will be replaced by a bigger One Stop Shop (OSS). Both non-EU and EU suppliers will be eligible to use the OSS. The scheme has two variants:

(1) non-Union scheme for non-EU established suppliers and (2) the Union Scheme for EU established suppliers. ${ }^{44}$

For non-EU suppliers under the non-Union scheme, OSS allows the suppliers of B2C services to register for VAT in one Member State (i.e., the Member State of identification) and to account in that Member State for the VAT due in all Member States to which relevant supplies are made. The non-EU vendor is free to choose the EU country in which it registers. Once the Member State of identification has received and validated the required registration detail, the information is stored in its database and forwarded to the other Member States. A taxable person using the non-Union scheme will, at this point, receive an individual VAT identification number from the Member State of identification.

Taxable persons using OSS are required to submit, by electronic means, a (mini) One Stop Shop VAT return for each calendar quarter whether or not it has actually made taxable supplies (where no supplies in the EU have been carried out for that quarter, a 'nil return' is submitted). The OSS VAT return (and accompanying payment) is required to be submitted within 20 days of the end of the period covered by the return.

The OSS VAT return contains the details of supplies made to customers in each Member State of consumption by the taxable person. The Member State of identification splits the VAT return by Member State of consumption, and forwards the details to the various Member States of consumption The Member State of identification generates a unique reference number for each OSS VAT return, and informs the taxable person of this number. The taxable person must make a reference to the number when it makes the corresponding payment.

42 Business-to-Business supplies of telecommunication, broadcasting, and electronic services are subject to the reverse charge.

43 Distance sales refer to both intra-Community sales of goods and services as well as sales of goods and services imported from third (non-EU) countries. Distance sales occur whenever goods or services are sold without face-to-face contact between the supplier and buyer (examples include sales made by internet, telephone, and TV shopping).

44 For additional details, refer to the European Commission Guide to the VAT mini One Stop Shop (MOSS), (October 2013, revised January 1, 2019) https://ec.europa.eu/taxation_customs/business/vat/ telecommunications-broadcasting-electronic-services/content/guide-vat-mini-one-stop-shop-moss 
The taxable person pays the VAT due to the Member State of identification. It pays one amount for the total of the return (i.e., for every Member State of consumption). The Member State of identification then distributes the money to the various Member States of Consumption.

The Union scheme operates in a similar way as the Non-Union scheme described above with three main differences:

(1) in addition to all B2C services, the Union scheme also applies to intra-Community distance sales ${ }^{45}$ of goods; and certain domestic supplies of goods facilitated by electronic interfaces (i.e., marketplaces).

(2) to support micro-businesses, an annual EUR 10000 turnover threshold has been introduced up to which the VAT on Intra-Community distance supplies of goods and telecommunications and electronic services to consumers (but not supplies of other types of services to EU consumers) is paid to the Member State where the supplier is established instead of where the consumer is located

(3) the supplier has the option to register in each of these Member States and declare and pay the VAT due in the national VAT return of the respective Member State or register for the Union scheme in the Member State where the supplier is established and use the OSS in that State for all of its cross-border distance sales of goods and services to customers in other EU countries.

The mechanics of the Union OSS scheme-in terms of tax return filing and payment processesare similar to those of the non-Union OSS scheme described above.

Low-Value Import Scheme. ${ }^{46}$ As from July 1, 2021 the VAT exemption at importation of small consignments up to EUR 22 will be removed and a new special scheme for the sales of goods imported from non-EU countries of a value not exceeding EUR 150 (excluding excisable goods) will be created and is referred to as the Import One Stop Shop (IOSS). The customs duty relief for goods with a value not exceeding EUR 150 imported into the EU remains in place.

The IOSS is voluntary: both EU and non-EU suppliers (vendors and marketplaces) can elect to pay VAT on low-value imports from countries outside the EU either through the IOSS regime, at import through normal customs procedures, or under special arrangements for postal operators and express carriers to charge VAT (as described below).

Like the MOSS and OSS regimes described above, the IOSS system allows non-EU businesses (vendors and marketplaces) to register, declare, and report VAT in a single EU Member State (i.e., the Member State of identification) for their sales to customers (both final consumers and businesses) in multiple Member States. The system then distributes the VAT payments among the Member States where the goods have been bought and consumed.

45 Distance sales refer to both intra-Community sales of goods and services as well as sales of goods and services imported from third (non-EU) countries. Distance sales occur whenever goods or services are sold without face-to-face contact between the supplier and buyer (examples include sales made by internet, telephone, and TV shopping).

46 For additional details, refer to European Commission Explanatory Notes on VAT E-Commerce Rules (September 2020) https://ec.europa.eu/taxation_customs/sites/taxation/files/vatecommerceexplanatory notes 30092020.pdf 
Upon registration for the IOSS, the tax authorities in the Member State of identification will issue an IOSS VAT identification number to suppliers or to marketplaces who are deemed suppliers The IOSS VAT identification number will be provided to the customs authorities in the customs declaration in order to release the goods without charging VAT a second time at import.

All of the IOSS VAT identification numbers issued by tax authorities in EU Member States will be made available electronically to all customs authorities in the EU. The customs authorities when receiving an IOSS VAT identification number in the dataset of the customs declaration will make an automatic check of its validity against the IOSS VAT identification number database. If the IOSS number is valid and the value of the consignment does not exceed EUR 150, the customs authorities will not request the payment of VAT on low-value goods imported under the IOSS.

Under the IOSS, the vendor or marketplace (deemed supplier) is responsible for ensuring the following:

- Collect from the customer the VAT on supplies of all eligible goods dispatched/transported to the EU (e.g., non-excise goods dispatched to an EU Member State in consignments not exceeding EUR 150).

- Make sure that eligible goods are shipped in consignments of a value not exceeding the EUR 150 threshold.

- Provide to the transporter/customs declarant of the goods (such as postal operators or express carriers or customs agent) the information required for the customs clearance in the EU, including the IOSS VAT identification number in order to avoid that VAT is levied a second time at import.

- Submit a monthly IOSS return to the Member State of identification for all the eligible supplies of goods sold to customers across the entire EU. The IOSS VAT return will contain the total value of the goods sold, their VAT rate and the total VAT amount to be paid, broken down for each EU Member State where the goods are transported to, as well as broken down in standard and reduced rate.

- Make a monthly payment to the Member State of identification of the VAT due as declared in the IOSS VAT return.

The customs authorities will prepare a monthly listing containing the total value of imports of low value goods declared in the EU for each IOSS VAT identification number based on the customs declarations submitted in each EU Member State. The aggregated monthly listings will be made available to tax authorities in the EU. The tax authorities will compare the total value of the transactions declared upon importation under each IOSS VAT identification number with the IOSS VAT returns submitted under the respective VAT IOSS identification number.

Taxable persons (vendors and marketplaces) who are not established in the EU or in a third country with which the EU has concluded a VAT mutual assistance agreement need to appoint an intermediary to be eligible to use the import scheme. The intermediary needs to be a taxable person established in the EU. He/she has to fulfil all the obligations under the import scheme on behalf of the supplier or electronic interface that appointed him/her, including the submission of IOSS VAT returns and payment of VAT on the distance sales of imported low value goods. 
The regime also includes special arrangements under which sellers and marketplaces may alternatively opt to pass the import VAT collections to postal operators, express carriers and customs agents.

Under the special arrangements, the customer pays the VAT to the declarant/person presenting the goods to customs. The Special Arrangements operators then pay the tax authorities on a monthly basis on a cash-received basis. The deadline is the 16th of the month following the month of import. 


\section{APPENDIX 2. EXAMPLE OF DETERMINING THE SCOPE OF THE VENDOR COLLECTION REGIME (SINGAPORE)}

Company A, established in Germany, aggregates accommodation availability from accommodation providers worldwide on its website and allows customers to search and book accommodation. Upon each confirmed booking, Company A charges a service fee to the respective accommodation providers in Singapore and a booking fee to customers in Singapore. Appendix Table 1 assesses the GST implications of the transaction under Singapore's vendor collection regime.

In reviewing the table below, it is useful to keep in mind that the service and booking fees are essentially charges for the services provided by the platforms (online marketplaces) to the accommodation providers and customers, and are different and separate from the accommodation charges. As the accommodation itself is provided by the accommodation providers (and not the platform), the accommodation charges (i.e. in respect of properties in Singapore) will be subject to Singapore GST, if the accommodation providers are GST-registered.

\section{APPENDIX Table 1. Determining the Scope of the Vendor Collection Regime}

\begin{tabular}{ll}
\multicolumn{1}{c}{ COMPANY A'S SERVICES } & \multicolumn{1}{c}{ VAT TREATMENT } \\
$\begin{array}{ll}\text { Service fees to non-GST registered Singapore } \\
\text { accommodation providers. }\end{array}$ & $\begin{array}{l}\text { Subject to Singapore's GST as services are within } \\
\text { scope and provided to a non-GST registered business. }\end{array}$ \\
$\begin{array}{l}\text { Booking fees charged to non-GST registered } \\
\text { Singapore customers. }\end{array}$ & $\begin{array}{l}\text { Subject to Singapore's GST as services are provided to } \\
\text { a non-GST registered customer. }\end{array}$ \\
$\begin{array}{ll}\text { Service/Booking fees to overseas persons. } & \text { Not subject to VAT as outside scope of the regime } \\
\text { because the fees are paid to an overseas supplier } \\
\text { and are considered to be for services (i.e., booking/ } \\
\text { brokerage services) consumed overseas. }\end{array}$ \\
$\begin{array}{ll}\text { Service/Booking fees to GST registered Singapore } \\
\text { persons. }\end{array}$ & Subject to reverse charge.
\end{tabular}




\section{APPENDIX 3. EXAMPLE OF DEEMING AN ELECTRONIC MARKETPLACE AS THE SUPPLIER FOR BUSINESSES THAT MAKE TAXABLE SUPPLIES ON THE PLATFORM (SINGAPORE)}

Electronic marketplace A is the operator of an online platform that sells phone applications on behalf of underlying application developers that utilize its platform. Electronic Marketplace B is a platform that provides hotel listing services to hotels, and the terms of the supply are privately arranged by the hotels and their customers. Appendix Table 2 assesses whether the marketplace is deemed to be the supplier based on the five criteria described in Section III.B.

\begin{tabular}{|c|c|c|}
\hline CONDITIONS & ELECTRONIC MARKETPLACE A & ELECTRONIC MARKETPLACE B \\
\hline $\begin{array}{l}\text { 1. Authorizes the charge to the } \\
\text { customer. }\end{array}$ & $\begin{array}{l}\text { Yes. A initiates the charging process } \\
\text { and receives payment from the } \\
\text { customer. }\end{array}$ & $\begin{array}{l}\text { No, Payment is separately settled } \\
\text { between buy and seller. }\end{array}$ \\
\hline $\begin{array}{l}\text { 2. Authorizes the delivery of supply } \\
\text { to the customer. }\end{array}$ & $\begin{array}{l}\text { Yes. A arranges for delivery of the } \\
\text { supply to the customer. }\end{array}$ & $\begin{array}{l}\text { No. Delivery is separately arranged } \\
\text { between buyer and seller. }\end{array}$ \\
\hline $\begin{array}{l}\text { 3. Sets the terms and conditions } \\
\text { under which the supply is made. }\end{array}$ & $\begin{array}{l}\text { Yes. A provides customer support } \\
\text { and sets return policy. }\end{array}$ & $\begin{array}{l}\text { No. Terms and conditions } \\
\text { separately negotiated between } \\
\text { buyer and seller. }\end{array}$ \\
\hline $\begin{array}{l}\text { 4. Supply identified as made by the } \\
\text { marketplace. }\end{array}$ & $\begin{array}{l}\text { Not Applicable. Depends on sales } \\
\text { arrangements. }\end{array}$ & No. \\
\hline $\begin{array}{l}\text { 5. Agreement that marketplace is } \\
\text { responsible for VAT. }\end{array}$ & No. & No. \\
\hline Conclusion: & $\begin{array}{l}\text { A is regarded as the supplier of the } \\
\text { digital services. }\end{array}$ & $\begin{array}{l}\mathrm{B} \text { is not regarded as the supplier of } \\
\text { the digital services. }\end{array}$ \\
\hline
\end{tabular}




\section{APPENDIX 4. EXAMPLE OF A SIMPLIFIED REGISTRATION FORM (NEW ZEALAND)}

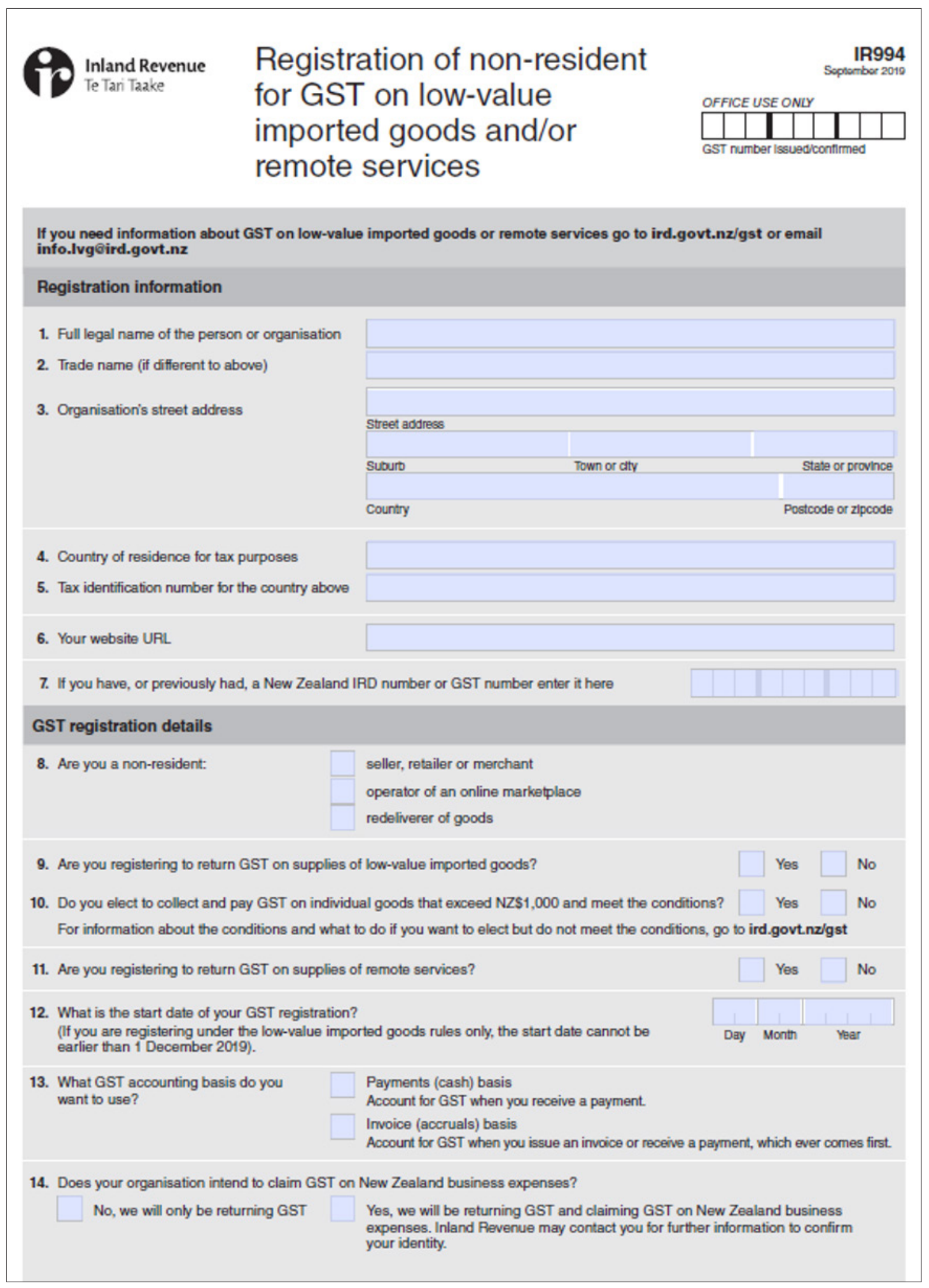




\section{First contact person}

15. Full name of the contact person

Designation or title

(eg finance officer, tax manager)

Contact email address

Contact phone number

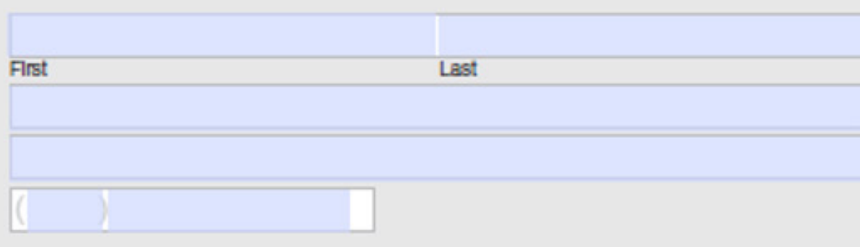

Second contact person

16. Full name of the contact person

Designation or title

(eg finance officer, tax manager)

Contact email address

Contact phone number

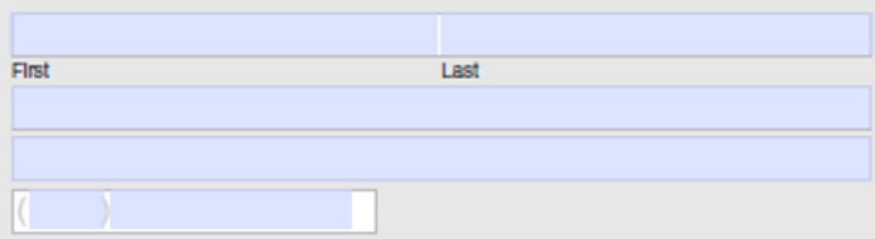

\section{Declaration}

In my own right or on behalf of the entity named in " 1 ", Wthe organisation declares:

- the information given on this form is true and correct.

- I/the organisation is a non-resident supplier, marketplace or redeliverer that is carrying out or intending to carry out a taxable activity in New Zealand which involves providing low-value imported goods and/or remote services to residents of New Zealand.

- I/the organisation give consent to communicating with Inland Revenue via email and accept that Inland fievenue will communicate via email where appropriate; understanding that at times these emails may contain confidential and/or commercially sensitive information.

- I/the organisation understand Inland Revenue will take all reasonable steps to mitigate any risk of emails being sent to the wrong recipient, but cannot guarantee that emails will not be intercepted while in transit.

- I/the organisation acknowledge that, once the email has been received, it is mylour responsibility to keep this information secure, and ensure it is not accessed by an unauthorised individual.

Full Name

\section{Signature}

$=$
Designation or title

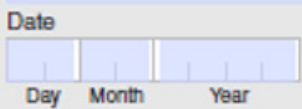

Please check that you have completed all sections, then sign the declaration.

Email the completed form to New Zealand Inland Revenue at info.Ivgeird.govt.nz

Privacy

Meeting your tax obligations means giving us accurate information so we can assess your liabilities or your entitlements under the

Acts we administer. We may charge penalties if you dont.

We may also exchange information about you with:

- some government agencies

- another country, if we have an information supply agreement with them

- Statistics New Zealand (for statistical purposes only).

If you ask to see the personal information we hold about you, we'll show you and correct any errors, unless we have a lawful reason not to. For full details of our privacy policy go to ird.govt.nz/privacy

\section{CInternational Monetary Fund. Not for Redistribution}


International Monetary Fund

Fiscal Affairs Department

ISBN-13: 978-1-51357-648-0

700 19th Street NW

Washington, DC 20431

USA

T. + (1) 202.623.8554

F. + (1) 202.623.6073 